\title{
Late Miocene siliceous endoskeletal dinoflagellates from the Sawai Bay Formation, Neill Island, Andaman Sea, India
}

\author{
JYOTSANA RAI \\ Birbal Sahni Institute of Palaeobotany, 53, University Road, PO Box 106, Lucknow, India (e-mail: jyotsana_rai@Yahoo.com)
}

\begin{abstract}
Siliceous spicules of endoskeletal dinoflagellates form a very small part of the siliceous microfossil assemblage from Neill Island, Ritchie's Archipelago, Andaman Island and Nicobar Island. They are represented here by a solitary genus, Actiniscus, with two species - Actiniscus pentasterias and Actiniscus elongatus. Light microscopy, supported by scanning electron microscopy, illustrates its remarkable symmetry and geometry. Though biostratigraphically unimportant, this genus has considerable value in deriving palaeoecological interpretations. Their association with age-diagnostic calcareous nannofossil taxa indicates that the glauconitic mudstones of the Sawai Bay Formation of Nipple Hill and East Coast sections are Late Miocene in age, equivalent to the Discoaster berggrenii Subzone (Subzone CN9A) corresponding to the lower part of the Discoaster quinqueramus Zone (Zone NN11). J. Micropalaeontol. 25(1): 37-44, April 2006.
\end{abstract}

KEYWORDS: Endoskeletal dinoflagellates, Actiniscus, Sawai Bay Formation, Neill Island, Late Miocene

\section{INTRODUCTION}

This paper records for the first time the presence of endoskeletal dinoflagellates in the Neogene succession of the Andaman area, India (Fig. 1). Endoskeletal dinoflagellates are a rare group of siliceous microfossils belonging to the family Actiniscaceae Kutzing (1844). The mineralized skeleton of Actiniscus pentasterias (known both in fossil and extant form) is found to be composed of opaline silica.

Of considerable interest is the structure shown by the most commonly recorded group of actiniscids. They are characterized by an alveolar structure which pervades their skeleton from the centre to the distal end of the arms. Species with such structures are represented more frequently in the Neogene than in the Palaeogene. A central or apical alveola is surrounded by the first row of 4-6 alveoli and it forms a ring-like or amphora-shaped central alveola with a central opening and a polygonal outline, known as an apical plate (Hovasse, 1932).

Literature on this rare group of microfossils is scarce; Ehrenberg (1840) first described five species of the genus Actiniscus. Dumitrica $(1968,1973)$ gave excellent illustrations and detailed accounts of such microfossils recovered from the Oligocene to Quaternary sediments from the SW Pacific. Perch-Nielsen $(1975,1976)$ recorded a rich assemblage from the Late Cretaceous to Pleistocene sediments of the Sub-Antarctic, the southwest Pacific and Eocene-Pliocene sediments of the Norwegian Sea. Orr \& Conley (1976) recorded the distribution of Miocene to Recent Actiniscus from about a dozen sites in the northeast Pacific. Dumitrica (1973) noted the interval from the Middle Miocene to the Early Pliocene to be extraordinarily rich in siliceous dinoflagellates.

The objective of the present study is to document a wellpreserved assemblage of endoskeletal dinoflagellates, represented by Actiniscus, from the sediments of Late Miocene age from Neill Island, Andaman Sea.

\section{GEOLOGY OF THE AREA}

The Andaman and Nicobar Islands lie in the Bay of Bengal and extend $\mathrm{N}-\mathrm{S}$ for $c .850 \mathrm{~km}$ between $6^{\circ} 45^{\prime} \mathrm{N}$ and $13^{\circ} 45^{\prime} \mathrm{N}$ latitude. This is an island-arc system representing peaks of a prominent oceanic rise, extending from eastern Burma to Sumatra and Java. It comprises an outer (western) non-volcanic arc which contains the major islands of Andaman and Nicobar, and an inner (eastern) volcanic arc representing Narcondum and Barren Islands, which are both mud volcanoes. Two sub-parallel submarine ridges occur to the east and west of the main Andaman and Nicobar belt. This region has been subject to several cycles of deformation during the Mesozoic, Palaeogene and Neogene.

Neill Island is one of the volcanic islands belonging to Ritchie's Archipelago, which have outcrops of Neogene sediments (Fig. 1). These islands owe their origin to Palaeogene uplift. The geology and stratigraphy of Neill Island is discussed by Oldham (1885), Gee (1927), Singh \& Vimal (1973) and Srinivasan \& Azmi (1976a). The eastern and northeastern part of Neill Island projects as prominent cliffs, comprising glauconitic mudstones of the Sawai Bay Formation (Srinivasan \& Azmi, 1976b) and are capped by the hard, fossiliferous Neill West Coast Formation which is characterized by molluscs and larger foraminifera. The latter formation has a heavy influx of clay material in the lower part which then grades into hard limestones. The lithostratigraphic framework is shown in Figure 2. Volcanic glass shards recorded from Neill Island (Rai, unpublished data) are indicative of inorganic silica exuded from the volcanic vents along mid-oceanic ridges during some phase of active tectonics in the Andaman Basin.

\section{PALAEONTOLOGY}

Neill Island exposes one of the deepest marine sedimentary sequences of Neogene age in India. Precise biozonations using both calcareous and siliceous microfossils have been established from the Sawai Bay Formation (Fig. 2), which also yielded the endoskeletal dinoflagellates recorded. Actiniscus is known from the Cretaceous (fide Deflandre, 1953); however, all other genera recorded are restricted to younger Tertiary sediments only. The presence of age-diagnostic microfossil groups - foraminifers (Srinivasan \& Azmi, 1976a), nannofossils (Singh \& Jafar, 1995), 


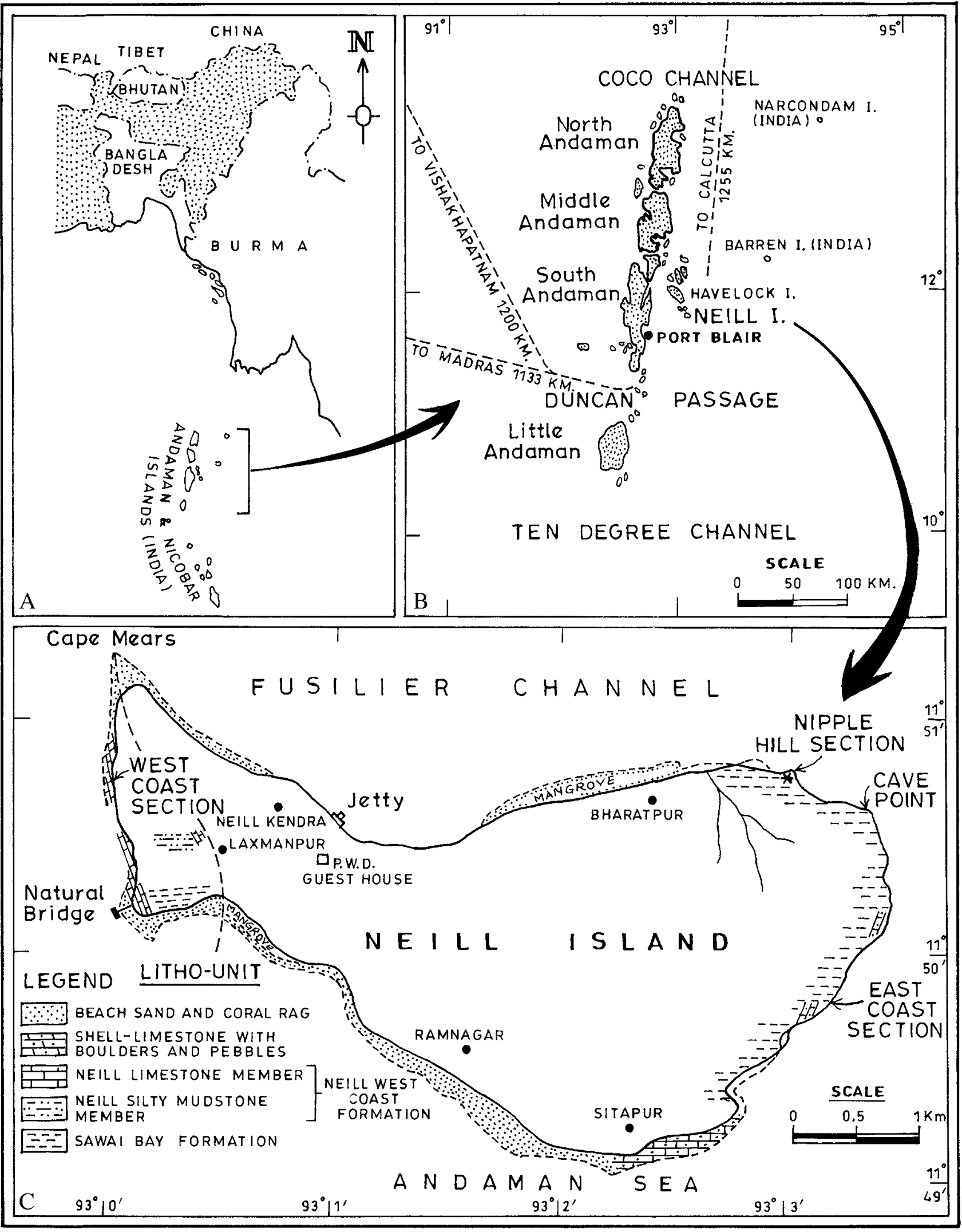

Fig. 1. (A) Inset map of part of India. (B) Location map of Andaman-Nicobar Islands. (C) Geological map of Neill Island showing the locations of the sections examined. 


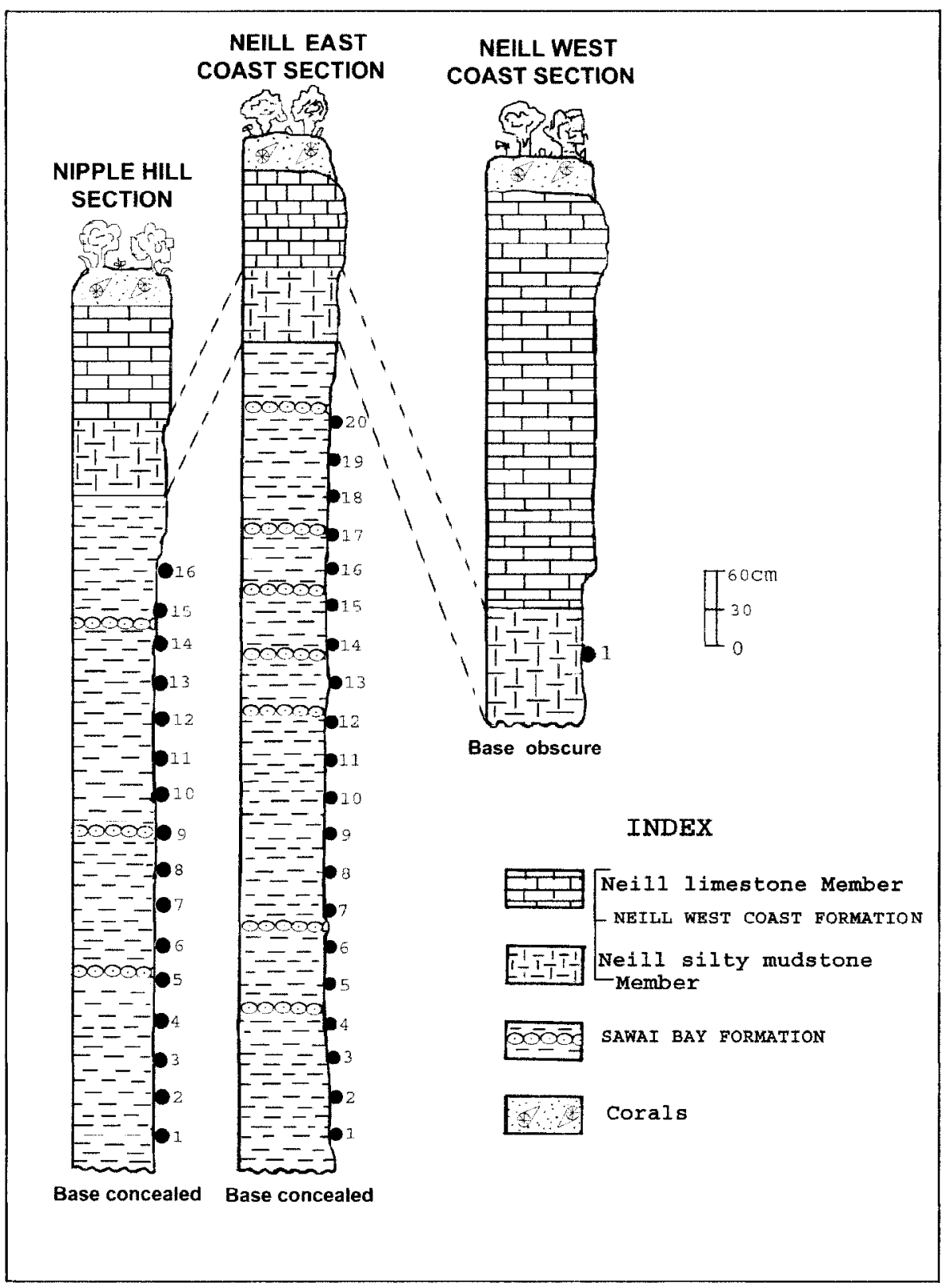

Fig. 2. Lithologs of the sections studied in Neill Island.

diatoms, silicoflagellates and radiolaria (Gupta \& Srinivasan, 1992) - from Neill Island confirms their occurrence in Late Miocene sediments (Fig. 3).

The nannofossil assemblage herein contains Calcidiscus macintyeri, Coccolithus miopelagicus, Cyclococcolithus leptoporus, Cy. luminis, Cy. rotula, Cyclicargolithus floridanus, Discoaster berggrenii, D. brouweri, D. calcaris, D. challengeri, D. druggii, D. formosus, D. neohamatus, D. pentaradiatus, D. pseudovariabilis, D. quinqueramus, D. surculus, D. variabilis, Helicosphaera carteri, H. obliqua, H. recta, H. scissura, H. selli, Pontosphaera callosa, Reticulofenestra abisecta, $R$. haqii, $R$. minuta, $R$. pseudoumbilica, Sphenolithus abies, S. moriformis, Scyphosphaera spp., Thoracosphaera granifera, Th. saxea and Th. tuberosa. The assemblage also shows reworking of Cretaceous and Palaeogene forms.

\section{MATERIAL AND METHODS}

Sixteen samples from the outcropping cliff sections of Nipple Hill and 20 samples from the Neill East Coast section were collected from the Sawai Bay Formation (Srinivasan \& Azmi, 1976b). One sample was also collected from the overlying Neill West Coast Formation (Fig. 2). All samples proved to be productive. Permanent strewn slides were prepared using standard techniques (Perch-Nielsen, 1985). Material was absorbed in distilled water and a drop of the dissolved material was spread 
evenly on a slide and dried over a hot plate, which was then mounted in Canada Balsam.

Light microscopic documentation was carried out using oil immersion objective $(100 \times)$ using the single polarizer on a Leitz polarizing microscope. Further material containing siliceous microfossils was crushed, powdered and dispersed in glycerine jelly and then mounted under a coverslip to study the morphological details of the specimens. This revealed orientation pattern of arms, structure of the central body, surface features and the nature of depressions on the rays and ray tips.

For scanning electron microscopy, stubs were prepared by spreading a few drops of suspension and drying over a circular coverslip which was fixed on a stub. Coating was with goldpalladium alloy and the material was examined using a Philips model 505 with $30.0 \mathrm{kV}$ acceleration voltage.

\section{SYSTEMATIC DESCRIPTIONS}

Dumitrica (1973) discussed the systematics of endoskeletal dinoflagellate genera recovered from Leg 21 of the southwestern Pacific and assigned them to the family Actiniscidae. He erected several new genera and species and gave a detailed description of species, along with sketches and light micrographs and a synonymy list, showing their relationship and distribution in time and space, thus highlighting their biostratigraphical potential.

Perch-Nielsen (1975), using both light and scanning electron micrographs, illustrated several species of the genera Actiniscus, Foliactiniscus and Carduifolia, with detailed descriptions from the Norwegian Sea, DSDP Leg 29. Perch-Nielsen (1976) additionally illustrated several species of the genera Actiniscus, Foliactiniscus, Carduifolia and Calcipedinium and a few siliceous forms similar to organic-walled dinoflagellates from DSDP Leg 38 of the Sub-Antarctic southwest Pacific.

The present material is restricted to the genus Actiniscus represented by the type species $A$. pentasterias with $A$. elongatus. It is noteworthy that these taxa are uniformly distributed in all the samples of the three studied sections of Neill Island. Their distribution ranges from rare to very rare, with only 1-3 specimens generally seen in ten fields of view $(100 \times)$.

Fensome et al. (1993) dealt with the details of this group in their catalogue of Dinoflagellates.

Division Dinoflagellata Fensome et al., 1993

Subdivision Dinokaryota Fensome et al., 1993 Class Dinophyceae Pascher, 1914

Subclass Gymnodiniphycidae Fensome et al., 1993 Order Gymnodiniales Apstein, 1909

Suborder Actiniscineae (Sournia, 1984) Fensome et al., 1993 Family Actiniscaceae Kutzing, 1844

Genus Actiniscus (Ehrenberg 1840) emend. Ehrenberg, 1843

Type species. Actiniscus pentasterias Downie \& Sarjeant, 1965

Occurrence. Actiniscaceans are marine planktonic and nonphotosynthetic micro-organisms. The marine fossil record of this siliceous skeletal group ranges from the Palaeogene to the Recent and they are at their most diverse during the Late Tertiary. Dumitrica (1973) and Perch-Nielsen (1975, 1976) discussed their palaeoecological importance.
Remarks. The genus Actiniscus is the earliest described form; Ehrenberg (1840) proposed Actiniscus as a subgenus of the silicoflagellate Dictyocha. He described two subspecies, Dictyocha (Actiniscus) pentasterias and D. (Actiniscus) sirius without designating a type for the subgenus Actiniscus. Actiniscus was subsequently raised to generic rank by Ehrenberg (1843). The type species of Actiniscus was first validly and legitimately designated by Downie \& Sarjeant (1965).

\section{Actiniscus pentasterias (Ehrenberg 1840) Downie \& Sarjeant, 1965 \\ (Pl. 1, figs 1-4, 6, 7, 9; Pl. 2, figs 1, 3, 4)}

1854 Actiniscus pentasterias Ehrenberg: pl. 18, fig. 61; pl. 19, fig. 45; pl. 20, fig. 48; pl. 33 (XVII), fig. 1; pl. 35A (XXIII), fig. 1; pl. 36 , fig. 36 .

1975 Actiniscus pentasterias Ehrenberg; Perch-Nielsen: 882, pl. 10, figs 2-10, 16.

1976 Actiniscus pentasterias Ehrenberg; Perch-Nielsen: 154, pl. 5, figs 1-7, 9-11; pl. 6, figs 9, 13-16.

1976 Actiniscus pentasterias Ehrenberg; Orr \& Conley: 92-99, pl. 1, figs $1-11$; pl. 2, figs $1-6$.

Description. The skeleton consists of opaline silica with a basal concave plate containing five rays and alveolar structures throughout. They show the phenomenon of extinction when seen under crossed nicols. The arms are tricostate, triangular in cross-section, curving down on the ventral side. The tapered arms vary in length and appear pointed at the distal ends. The arms contain alveolar structures and transverse wrinkles as ornamentation on the furrows and between the median and lateral crests. A central amphora-shaped pentagonal alveola is surrounded by five peripheral alveoli.

Dimensions. The distance between two arms is between $10 \mu \mathrm{m}$ and $15 \mu \mathrm{m}$.

Stratigraphic range. The known range is Late Eocene to Recent, but it is recorded as the most common siliceous endoskeletal dinoflagellate in most Miocene and Pleistocene samples and is the only representative in the Pleistocene (Perch-Nielsen, 1975, 1976). Orr \& Conley (1975) stated that thinner forms were noticed in the Pleistocene whilst robust forms dominated older intervals. This shift from robust to delicate specimens appears to be gradual throughout its distribution.

Remarks. Dumitrica (1973) recorded the variation in the number of arms from 4 to 6. Perch-Nielsen (1975) recorded forms with 5-8 arms. The present material, however, shows only 5-rayed forms. Orr \& Conley (1976) also recorded only 5-rayed $A$. pentasterias from the northeast Pacific rim.

Actiniscus elongatus Dumitrica 1968

(Pl. 1, fig. 5; Pl. 2, figs 2, 8)

1968 Actiniscus elongatus Dumitrica: 240, pl. 4, figs 22, 26.

1973 Actiniscus elongatus Dumitrica; Dumitrica: pl. 3, figs 6-12; pl. 5, figs 10-11. 
Miocene siliceous dinoflagellates from India
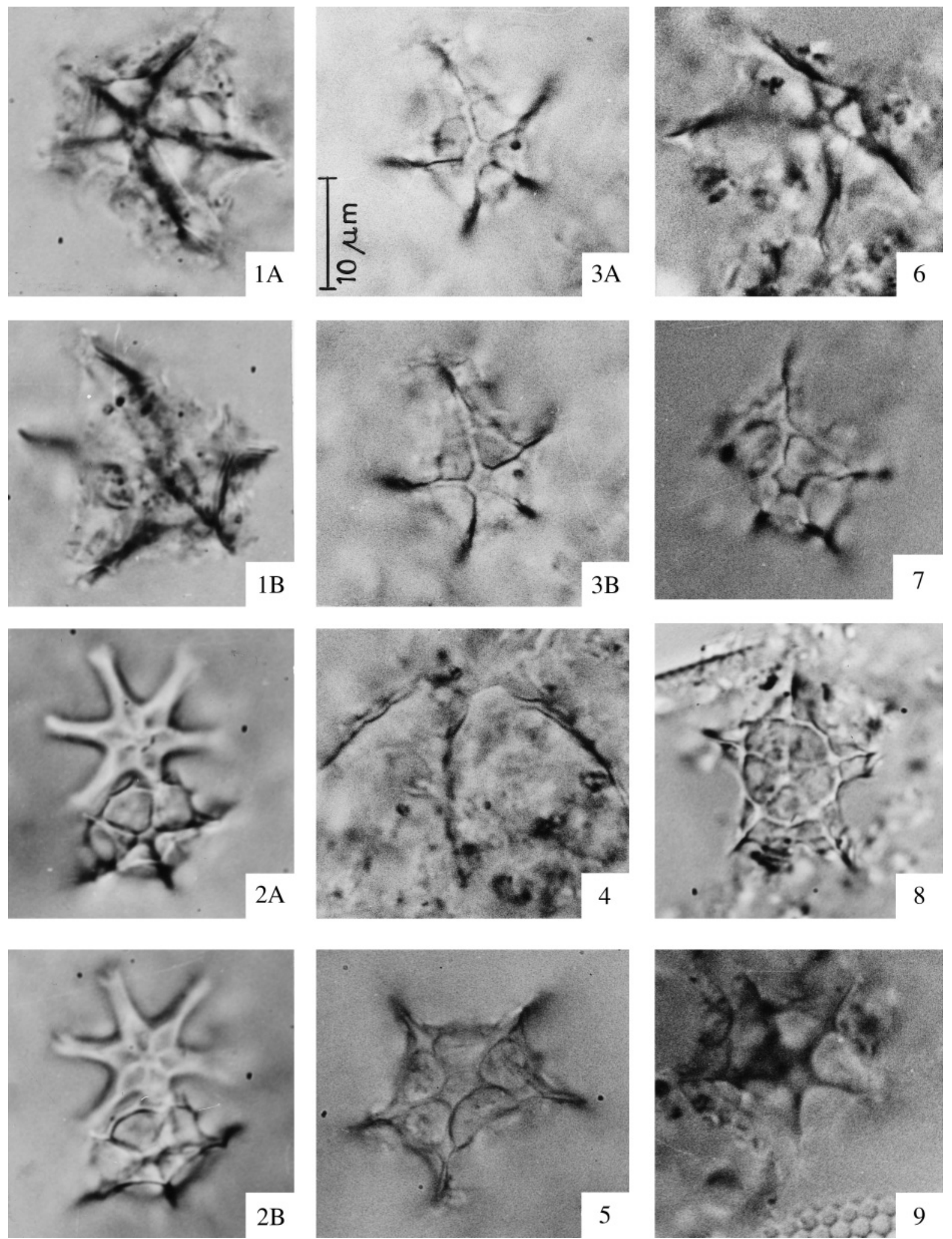

Explanation of Plate 1.

fig. 1A, B. Actiniscus pentasterias Ehrenberg: (A) dorsal view; (B) arm tips in focus. fig. 2A, B. Actiniscus pentasterias Ehrenberg: (A) central area in focus; (B) lower arms in focus. fig. 3A, B. Actiniscus pentasterias Ehrenberg: (A) central area in focus; (B) arms in focus. fig. 4. Actiniscus pentasterias Ehrenberg displaying highly curved nature of rays. fig. 5. Actiniscus elongatus Dumitrica, dorsal view. fig. 6. Actiniscus pentasterias Ehrenberg showing tricostate ray tips. fig. 7. Actiniscus pentasterias Ehrenberg, central area and two rays in focus. fig. 8. Actiniscus pentasterias Ehrenberg, dorsal view. fig. 9. Actiniscus pentasterias Ehrenberg Dorsal view. Each figure is $2000 \times$. 

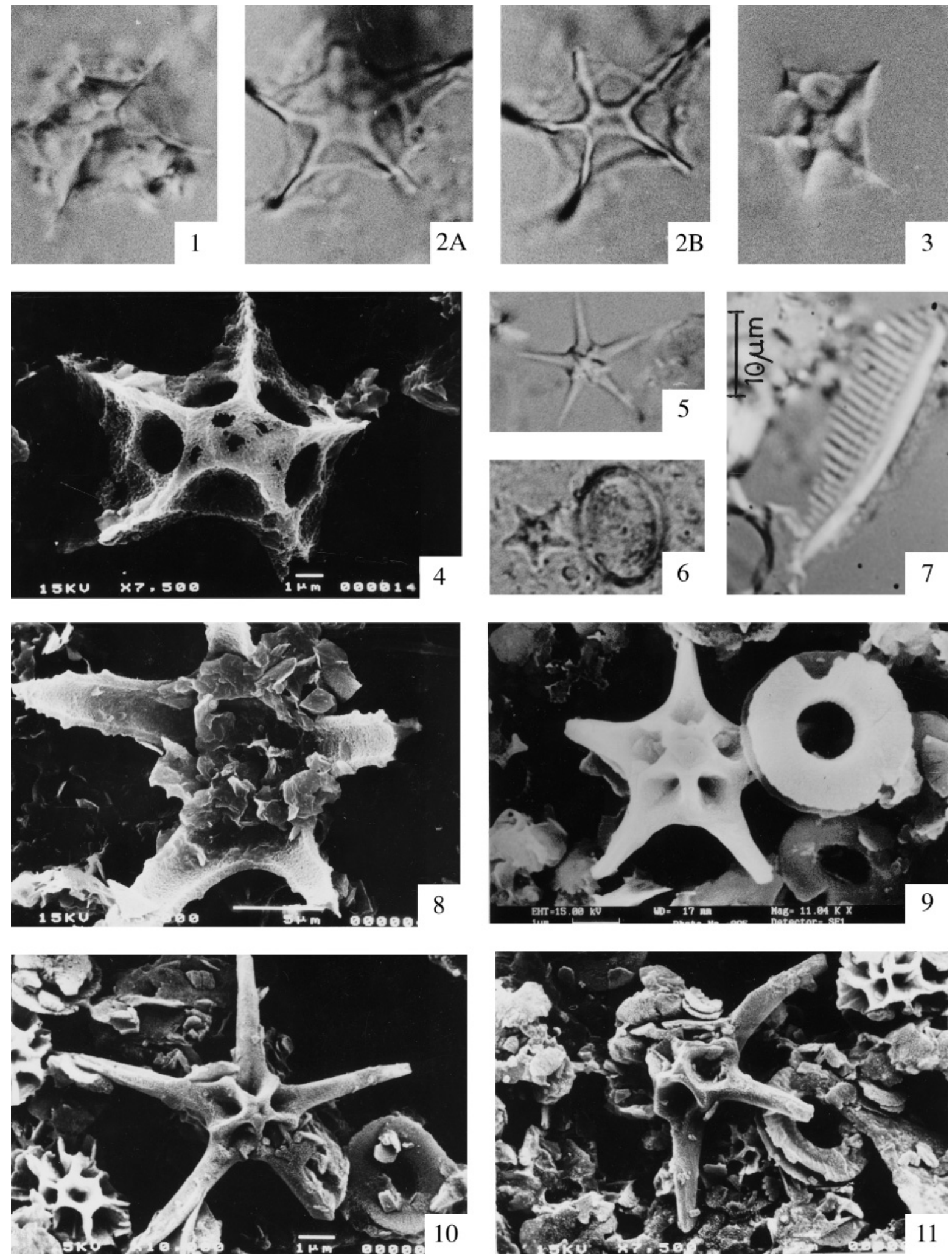

Explanation of Plate 2.

fig. 1. Actiniscus pentasterias Ehrenberg, dorsal view. fig. 2A, B. Actiniscus elongatus Dumitrica, dorsal view. fig. 3. Actiniscus pentasterias Ehrenberg, dorsal view. fig. 4. Actiniscus pentasterias Ehrenberg, dorsal view. fig. 5. Discoaster quinqueramus Gartner. fig. 6. Discoaster berggrenii Bukry. fig. 7. Triquetrorhabdulus rugosus Lipps. fig. 8. Actiniscus elongatus Dumitrica, ventral view. fig. 9. Discoaster berggrenii Bukry, dorsal view. fig. 10. Discoaster berggrenii Bukry/Discoaster quinqueramus Gartner (intermediate form). fig. 11. Discoaster berggrenii Bukry, side view. 
1975 Actiniscus elongatus Dumitrica; Perch-Nielsen: 882, pl. 10, figs 11-13.

1976 Actiniscus elongatus Dumitrica; Perch-Nielsen: 154, pl. 5, figs $13-14$.

Description. A star-like skeleton which consists of an elongate, pentagonal plate with bilateral symmetry. Five arcuate arms depart from the corners of this pentagonal plate; two of these arms are situated at one extremity whilst the three arms are present at the opposite extremity. The median crests of the arms join together apically and outline the elongate pentagon with a concave surface.

Dimensions. In the longitudinal dimension the span of the skeleton is $10-15 \mu \mathrm{m}$.

Stratigraphic range. Dumitrica (1976) recorded A. elegans from the Middle Miocene to Early Pliocene, but Perch-Nielsen (1975) found it from the Late Eocene to the ?Early Pliocene, and indicated it was rarely present in the Miocene (Perch-Nielsen, 1976). It is also rarely found in the present material.

Remarks. The central area appears simple in the present material and not divided by one or two wrinkles, as discussed by Dumitrica (1968). The arms indicate the presence of transverse wrinkles in the present specimens and are not smooth.

\section{AGE OF THE ASSEMBLAGE}

Srinivasan \& Azmi (1976) have identified Globorotalia plesiotumida, G. tumida tumida and Sphaeriidinella dehiscens planktic foraminiferal zones in ascending order from Sawai Bay and Neill West Coast formations and assigned Late Miocene to Early Pliocene age. Gupta \& Srinivasan (1992) identified Didymocyrtis antepenultima, D. penultima and Stichocorys peregrina radiolarian Zones of Late Miocene to Early Pliocene age for the same set of samples. Singh \& Vimal (1973) provided an Early Pliocene age on preliminary study of foraminifer and nannofossils from grey mudstone of the East Coast section. However, Singh \& Jafar (1995), after studying calcareous nannofossils from Neill Island, assigned NN 11=CN9A for the Sawai Bay Formation but did not comment upon the age of the overlying Neill Limestone Formation.

The presence of the nannofossil markers Discoaster berggrenii and Discoaster quinqueramus in all the samples from Nipple Hill and the Nipple East Coast Section of the Sawai Bay Formation, Neill Island, indicate that the assemblage lies in the Discoaster berggrenii Subzone CN9A of Okada \& Bukry (1980), corresponding to the lower part of the Discoaster quinqueramus (NN11) Zone of Martini (1971).

$D$. berggrenii and $D$. quinqueramus are poorly preserved both in diversity and frequency amongst the entire discoaster assemblage from the Neill West Coast section. The presence of Triquetrorhabdulus rugosus further restricts the age to a slightly younger (CN 9B) zonal attribution and within NN11 Zone.

\section{CONCLUSIONS}

1. Rare occurrences of siliceous dinoflagellates represented by the genus Actiniscus are recorded from Late Miocene sediments of Neill Island, India.
2. These siliceous dinoflagellates occur in association with rich and datable calcareous (planktonic foraminifers and calcareous nannofossils) and siliceous (diatoms, radiolaria) microfossils.

3. The siliceous dinoflagellates occur within the nannofossil $D$. quinqueramus (NN11) Zone of Martini (1971), corresponding with CN9 Zone of Okada \& Bukry (1980). The Sawai Bay Formation belongs to the (CN9A) D. berggrenii Zone, while the Neill West Coast Formation is assigned to the (CN9B) T. rugosus Zone, both of which occur within the NN11 Zone of Late Miocene age.

\section{ACKNOWLEDGEMENTS}

The author is greatly indebted to Prof. Anshu K. Sinha, Director of the Birbal Sahni Institute of Palaeobotany, Lucknow for providing a work facility and constant encouragement. Thanks are extended to Dr A. K. Jauhari, Geology Department, Lucknow University, Lucknow for critically reviewing the manuscript. Constructive suggestions by the referees have considerably helped in the improvement of the manuscript. Mr V. P. Singh is thanked for preparation of illustrations.

\section{Manuscript received 20 December 2001 Manuscript accepted 27 June 2005}

\section{REFERENCES}

Deflandre, G. 1953. Étude des Coccolithophoridé des vases actuelles au microscope électronique. Orientation desparticules élémentaires de calcaire en rapport avec les notions d'Heliolithae et d'Ortholithae. Comptes Rendus hebdomadaires Académie des Sciences, Paris, 234: 2100-2102.

Downie, C. \& Sarjeant, W.A.S. 1965. Bibliography and index of fossil dinoflagellates and Acritarchs. Geological Society of America Memoir, 94: $180 \mathrm{pp}$.

Dumitrica, P. 1968. Consideratii micropaleontologice asupra orizontului argilos cu radiolari din tortonianul regiunii Carpatice. Studii si Cercetari de Geologie, Geofizca Geografie, Bucharest, Serie Geologie, 13: $227-241$.

Dumitrica, P. 1973. Cenozoic endoskeletal dinoflagellates in southwestern Pacific sediments cored during Leg 21 of the DSDP. In: Burns, R.E. \& Andrews, J.E. (Eds), Initial Reports of the Deep Sea Drilling Project, 21. US Government Printing Office, Washington, 819-835.

Ehrenberg, C.G. 1840. Über noch jetzt zahlreich lebende Thierarten der Kreidebildung und den organismus der polythalamien. Königlich Perussische Akademie der Wiessenschaften zu Berlin, Bericht über die zur Bekanntmachung geeigneten verhandlungen, 1839: 81-174.

Ehrenberg, C.G. 1843. Über die Verbreitung des jetzt wirkenden kleinsten organischen Lebens in Asien, Australien und Afrika und über die vorherrschende Bildung auch des Oolithkalkes der Juraformation aus kleinen polythalamischen Thieren. Königlich Preussische Akademie der Wiessenschaften zu Berlin, Bericht über die zur Bekanntmachung geeigneten Verhandlungen, 1843: 100-106.

Ehrenberg, C.G. 1854. Mikrogeologie. Das Erden und Felsen schaffende wirken des unsichtbaren kleinen selbständigen Lebens auf der Erde. $374+31+88$ p, Leipzig, Leopold Voss.

Fensome, R.A., Taylor, F.J.R., Norris, G., Sarjeant, W.A.S., Wharton, D.I. \& Williams, G.L. 1993. A classification of living and fossil Dinoflagellates. Micropaleontology Special Publication, 7: 351pp.

Gee, E.R. 1927. The Geology of the Andaman and Nicobar Islands with special reference to Middle Andaman. Records of the Geological Survey of India, 59: 208-232.

Gupta, S.M. \& Srinivasan, M.S. 1992. Late Miocene radiolarian biostratigraphy and paleoceanography of Sawai Bay Formation, Neill Island, Andamans, India. Micropaleontology, 38: 209-235. 
Hovasse, R. 1932. Troisième note sur les èbriacées. La Société Zoologique de France, Bulletin, 57: 457-476.

Martini, E. 1971. Standard Tertiary and Quaternary calcareous nannoplankton zonation. In: Farinacci, A. (Ed.), Proceedings of the II Planktonic Conference Roma, 2. Edizioni Tecnoscienza, Rome, $739-785$.

Okada, H. \& Bukry, D. 1980. Supplementary modification and introduction of code numbers to the low latitude coccolith biostratigraphic zonation (Bukry 1973, 1975. Marine Micropaleontology, 5: 321-325.

Oldham, R.D. 1885. Notes on the Geology of the Andaman Islands. Records of the Geological Survey of India, 18: 135-145.

Orr, W.N. \& Conley, S. 1976. Siliceous dinoflagellates in the northeast Pacific rim. Micropaleontology, 22: 92-99.

Perch-Nielsen, K. 1975. Late Cretaceous to Pleistocene Archaeomonads, ebridians, endoskeletal dinoflagellates and other siliceous microfossils from the subAntarctic southwest Pacific, DSDP, Leg 29. In: Kennett, J.P. \& Houtz, R.E. (Eds), Initial Reports of the Deep Sea Drilling Project, 29. US Government Printing Office, Washington, 873-907.

Perch-Nielsen, K. 1976. Eocene to Pliocene archaeomonads, ebridians and endoskeletal dinoflagellates from the Norwegian Sea, DSDP Leg 38. In: Talwani, M. \& Udintsev, G. (Eds), Initial Reports of the Deep
Sea Drilling Project, 38. US Government Printing Office, Washington, 147-175.

Perch-Nielsen, K. 1985. Silicoflagellates. In: Bolli, H.M., Saunders, J.B. \& Perch-Nielsen, K. (Eds), Plankton Stratigraphy. Cambridge University Press, London, 811-846.

Singh, O.P. \& Jafar, S.A. 1995. Late Miocene discoasters from Sawai Bay Formation, Neill Island, Andaman Sea, India. The Palaeobotanist, 44: 189-206.

Singh, P. \& Vimal, K.P. 1973. A note on the a Geology and micropalaeontology of the Neill Island, South Andaman. Current Science, 42: 239-341.

Srinivasan, M.S. \& Azmi, R.J. 1976a. Contribution to the stratigraphy of Neill Island, Ritchie's Archipelago, Andaman Sea. In: Srinivasan, M.S. (Ed.), Proceedings of the VI Indian Colloquium on Micropaleontology and Stratigraphy. Devijyoti Press, Pandey Howly, Varanasi, 283-301.

Srinivasan, M.S. \& Azmi, R.J. 1976b. New developments in the Late Cenozoic Lithostratigraphy of Andaman-Nicobar Islands, Bay of Bengal. In: Srinivasan, M.S. (Ed.), Proceedings of the VI Indian Colloquium on Micropaleontology and Stratigraphy. Devijyoti Press, Pandey Howly, Varanasi, 302-327. 